\title{
The future of social housing in Eastern Europe: Reforms in Latvia and Ukraine
}

\author{
Sasha Tsenkova and Bengt Turner
}

Dr Sasha Tsenkova, Associate Professor in International Development, University of Calgary, 2500 University Drive NW, Calgary, T2N 1N4, Canada; tel:+403-220-2155, fax: +403-284-4399; e-mail: tsenkova@ucalgary.ca

Dr Bengt Turner, Professor, Institute for Housing and Urban Research, Uppsala University Box 785, 801 29, Gävle, Sweden; tel: +46 2642065 28, fax: +46 2642065 01; E-mail: Bengt.Turner@ibf.uu.se

\begin{abstract}
This paper explores the impact of housing reforms on public rented housing in Eastern Europe, using Latvia and Ukraine as case studies. The focus on public housing is important, since in both countries municipalities and state institutions are the major social landlords. Rent structures are not sensitive to demand or quality of housing services and allocation decisions rely on bureaucratic processes. The study evaluates changes in ownership, rent and allocation policies in the two countries to determine the extent to which public housing has moved away from a 'command' system to a more market sensitive model. The limited success of housing reforms, particularly in Ukraine, has critical implications for the financial sustainability of the sector. Drawing on comparative work on social rented housing provision in Western Europe, the paper argues that in transition economies where the sector is large, reforms need to focus on rent policies that ensure cost recovery for services with targeted 'in cash' support for low income households. By contrast, in countries where the sector is small, reforms need to define its social character and role in the provision of 'in kind' subsidy.
\end{abstract}

Keywords: Housing policy, social housing, Eastern Europe, Latvia, Ukraine

\section{INTRODUCTION}

The transition from a command to a market-based housing sector in Eastern Europe has major implications for more than 450 million people. Across the region the sector has become the 'shock absorber', providing some stability and security within a framework of rapid economic and social change (Struyk 1996). A decade after the initial reforms, housing markets have shown some signs of recovery, but housing production has remained historically low, the existing stock has deteriorated and homelessness has increased. On the 
fiscal side, most of the reform efforts so far have centered on the elimination of production and consumption subsidies for housing, which has led to major decline in public housing investment (Hegedus et al. 1996; Stephens 2002). On the financial side, policy reforms have supported the transition from a highly subsidized system of housing finance to a system driven by private initiative and real costs of housing services to consumers (Renaud 1996; Struyk 2000). Housing policies have been marked by emphasis on privatization of public housing and general deregulation of housing markets (Clapham et al. 1996; Marcuse 1996). As the flagship of real estate reforms, privatization of public housing has fuelled the expansion of home ownership, creating 'nations of homeowners' with levels of home ownership higher than 80 per cent (Tsenkova 2000).

While earlier comparative studies have focused on similarities in the reform process (Turner et al. 1992; Clapham et al.1996), recent comparative research has emphasised the importance of path dependency (Pishler-Milanovitch 2001) and divergence depending on policy choices (Tsenkova 2003a; Buckley and Tsenkova 2001). This paper supports the view that housing systems in Eastern Europe will become more diverse in the future and the diverging performance of their housing markets will increasingly depend on the consistency and coherence of policy reforms. In particular, the choices made with respect to the social rented housing will be critical in defining the type of housing system that is emerging and correspondingly the housing policy regime. In this context, it is important to ask what is the future of social rented housing in Eastern Europe? How would the size of the sector, its institutional structure and ways of operation affect its character? How would differences between countries in the post-privatisation phase influence the housing reform path? Is it possible to identify divergent scenarios for the social rented sector in Eastern Europe based on the Western European experience?

The paper treats these questions drawing on concepts and models developed by Kemeny in his analysis of social rented housing in Western Europe (Kemeny 1995). It has the following objectives:

- To present a comparable profile of the social rented sector in Latvia and Ukraine with an emphasis on changes in ownership, rent, allocation policies and sources of financing;

- To provide recommendations on policy reforms in the two countries that will improve asset management of the social rented sector and enhance its sustainability.

The paper has three major parts. First, critical differences in the Western European models of social rented housing are illustrated using new data on rent levels, share of households supported by housing allowances and sector size. Second, the analysis explores the impact of housing reforms on public housing in Eastern Europe focusing on two case studies Latvia and Ukraine. Both countries have the legacy of a Soviet housing system that operated for forty years, but have a different reform trajectory. Using Kemeny's models the comparison looks at privatisation, rent and allocation policies affecting public housing in the two countries. Third, the concluding comments highlight major challenges for the sector and explore alternative options for reform based on the Western European experience. The research draws on qualitative and quantitative methods for data collection. Key-person interviews were carried out in Riga (Latvia) in May 2000 and May 2002 and in Kiev (Ukraine) in June 2003. 


\section{MODELS OF SOCIAL RENTED HOUSING IN WESTERN EUROPE}

Despite general difficulties in defining social rented housing, Harloe (1995) has pointed out two essential characteristics: it is provided by landlords that are not profit-motivated and is administratively allocated according to 'need'. Several authors have analysed the development of the social rented sector in Western Europe pointing to a wide range of differences and similarities (Oxley and Smith 1996; Heijden 2001). Kemeny's (1995) influential comparative housing study distinguished between dual systems, based on direct competition between the social rental sector and other tenures, and unitary systems derived from a social market strategy. In a dual system the government uses the social rented sector as a safety net for low-income groups. It is characterised by several institutional arrangements - state ownership and management, rent setting policies insensitive to demand and allocation driven by bureaucratic procedures. Such 'command' system of social rented housing usually operates when the sector is small and residualised. By contrast, in unitary systems the balance between tenures is determined by household demand and the social sector is not exclusively directed towards low-income households. In some North-Western European countries, according to Kemeny, the sector operates like a 'social market'. The institutional arrangements favour non-state ownership by landlords not motivated by profit, rents are set below market level but tend to be sensitive to demand and allocation extends access to a more diverse income group.

Although there is no homogeneous European form of provision of social rented housing, countries in the 'north-west' appear to have a larger share of the stock managed by a greater diversity of social landlords - municipal companies, housing associations, non-profit and private landlords. Distortions in pricing are less prevalent, since 'cost' rental systems not only ensure cost recovery for services, but allow rent setting to be adjusted to a range of property attributes (e.g. in The Netherlands, Sweden and Denmark). By contrast, countries in the 'south-west' have a smaller social housing sector, managed by public landlords. The government shields the sector from competition and uses it as safety net. The two figures below illustrate these relationships using data from the European Household Consumer Panel. Figure 1A presents two variables -- rents in the social rented sector and its share for different countries in the European Union in 2000. We are using private sector rents as a benchmark for competitiveness in rent setting policies. The data demonstrates that in countries with a 'social market' model rents in the social rented sector are competing and/or exceed private sector rents (e.g. The Netherlands, Denmark, Sweden and Austria). By contrast, in the 'command systems' with a small social rented sector (e.g. Italy, Portugal and Ireland), rents are almost half of private sector rents since it houses mostly low-income households.

Despite the ideosyncracies of a given tenure in each country, the relative size of the social rented sector affects its character. Allocation policies determine the socio-economic profile of tenants, and the share of low income households. Figure 1B illustrates some of these outcomes presenting comparable data on sector size and percentage of households receiving housing allowances in 15 European countries in 2000. Although the pattern is less consistent, the data demonstrates that 'south-west' countries with a smaller social rented sector targeting vulnerable households, provide 'in kind' rather than 'in cash' subsidies (e.g. Portugal, Italy, Spain). On the other hand, countries, which have a large 
social sector, manage it in a more competitive way with rents based on cost recovery, combined with housing allowances or other direct household subsidies. Some of the differences among countries are no doubt a result of broader patterns of income inequality (e.g. Britain) and the type of social security system in operation (e.g. France and The Netherlands).

Figure 1A Rents in Social Rented Sector as a Share of Rents in Private Rental Sector combined with the Share of Social Rental Sector in Total Housing Stock for Different EU Countries in 2000

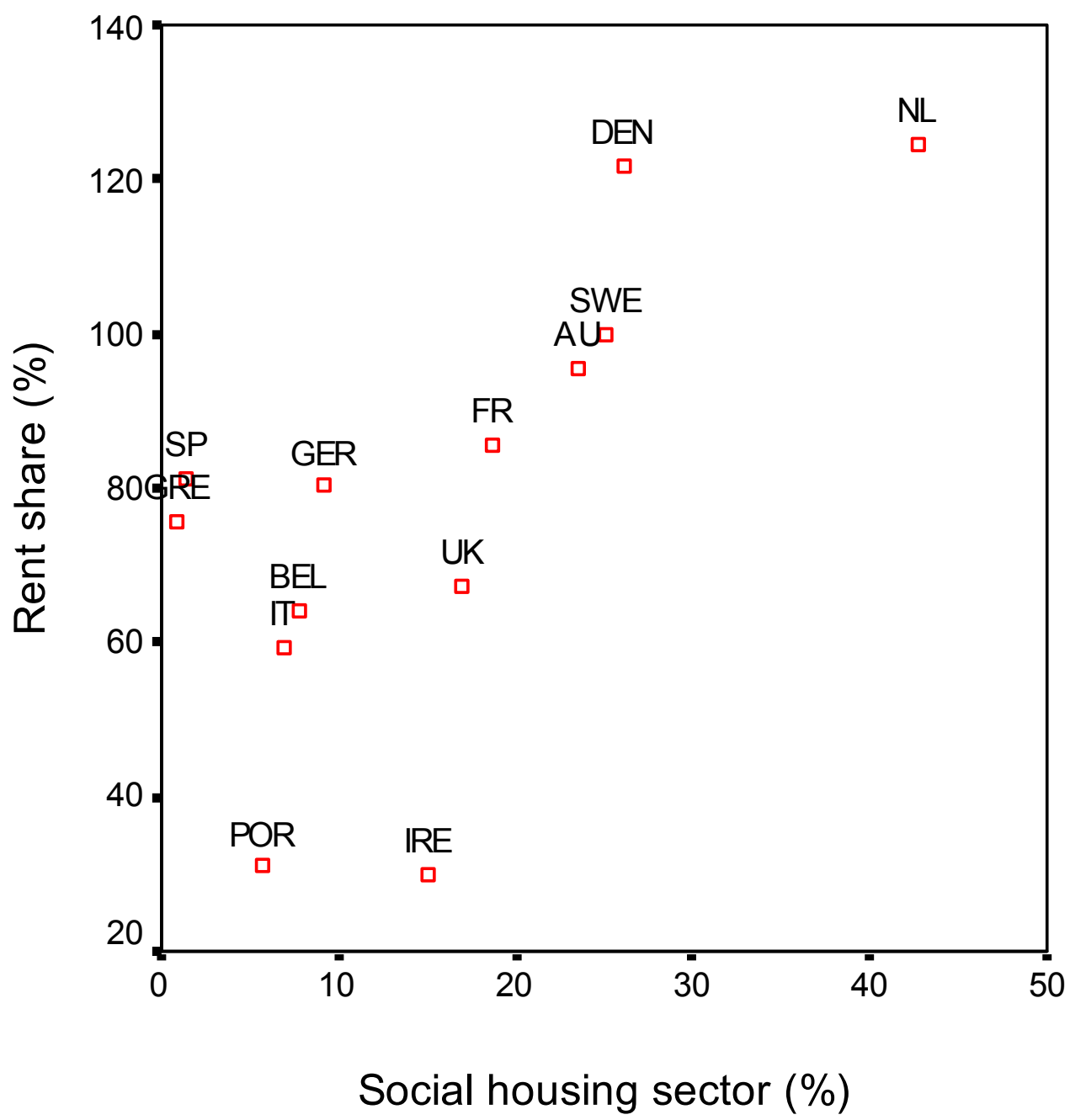

Source: Authors' estimates based on data in European Household Consumer Panel and Bostads-och Hyresundersökningen for Sweden 
Figure 1B Housing Allowances in Social Rented Sector as a share of gross

Housing Expenditures combined with the Share of Social Rented Sector

in Total Housing Stock for Different EU Countries in 2000

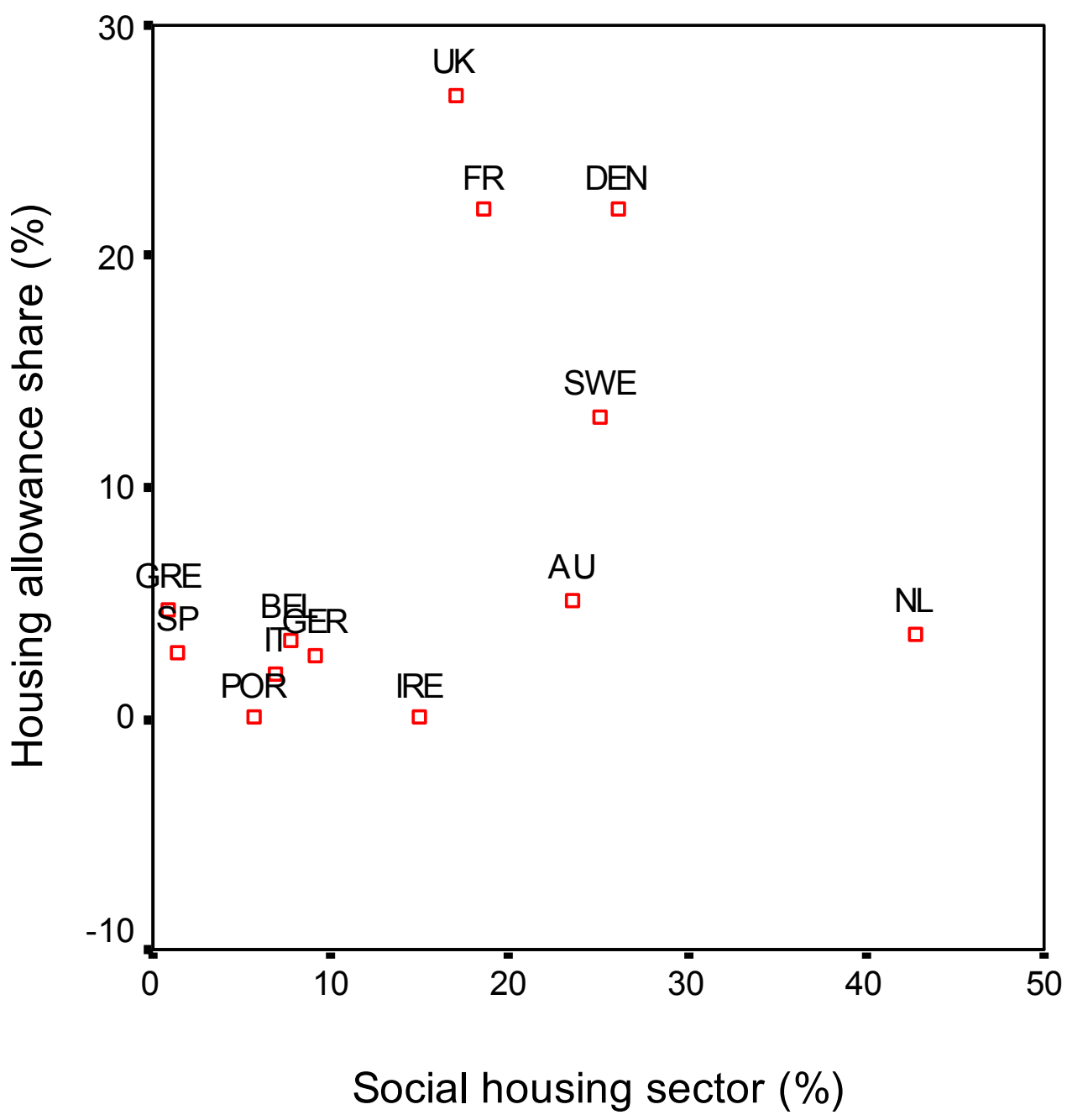

Source: Authors' estimates based on data in European Household Consumer Panel and Bostads-och Hyresundersökningen for Sweden

These relationships sketched in broad strokes reflect very general aspects of the role of the social rented sector its character and asset management policies in different national housing systems. It should be recognised that the size of the sector, the position of social landlords and their strategies have evolved in response to changes in the wider economic, social and political context. Specifically, in some countries, such as Britain, the social rented sector despite its size has been characterised as a 'command system' (Stephens 
2003; Kemeny 1995). In Germany, the large private rented sector has a social function. Dwellings are used for vulnerable households supported through housing allowances to cover the difference between 'social' and 'cost' rent. The special agreements (socialwohnungen) allow the dwelling to be transferred to the private rented sector once the subsidized loan has been repaid.

The analysis of the models of social rented housing in Western Europe informs the discussion on policy reforms affecting the sector in Eastern Europe. The emphasis is on changes in ownership and rent policies.

\section{THE SOCIAL RENTED SECTOR IN EASTERN EUROPE}

East European countries, particularly the ones in the former Soviet Block, have the legacy of an excessively controlled 'command' housing system, which operated till the early 1990s. The system was based on low housing costs, centralised production and state control over housing allocation. Home ownership, particularly in urban areas, was discouraged; all housing was universally affordable due to extensive subsidies and macroeconomic regulation of prices. The bureaucratic allocation was administered through 'waiting lists' for housing maintained by municipal housing authorities. Large volumes of public housing were produced, while little was invested in the maintenance and upkeep of the existing stock (Tsenkova 2000). It is important to note that there were differences among national systems, including reliance on 'encapsulated market solutions' (e.g. Yugoslavia, Bulgaria and Hungary). The 1990s have marked a departure from the 'command system' with deregulation of housing markets and privatisation of public housing being the flagship of the reform process. In the context of this shift away from direct state intervention to market-based provision of housing services, municipalities have emerged as the new social landlords with major responsibilities for housing the poor and disadvantaged. These trends are somewhat similar across Eastern Europe (Lux 2003, UNECE 2003).

In most countries, as a result of mass privatisation, the size of the social rented sector has been reduced mostly through transfer to sitting tenants (free of charge, through vouchers or nominal fee) (Clapham et al. 1996). While these populist policies have been equally attractive across the region, governments have been reluctant to introduce less popular measures such as cost recovery of rents or deregulation of maintenance and management (Lux 2003; Tsenkova 2002). Despite these similar policies, the size of the sector across the region is quite different (Figure 2).

In recent years, East European countries have chosen different strategies to address major issues related to access, management and financing of social rented housing. While these strategies have not been explored in a systematic manner, there seems to be a consensus that the countries are moving in the same direction -- towards residualization (UNECE 2003). In fact, the developments in the social rented sector of Western Europe might prompt two diverging scenarios. In countries where the sector is small (e.g. Albania, Estonia, Hungary), it might be moving towards a residual model, operating as a 'command system' which targets low-income households. In countries where the sector is of considerable size (e.g. The Czech Republic, Russian Federation, Latvia), it might be expected to evolve as a 'social market', being the home of a mix of income groups. East 
European countries in the future might be moving 'north-west' or 'south-west', depending on starting point, social policy ambitions/legacy and the size of the social rented sector.

These issues are explored in the next sections using Latvia and Ukraine as case studies. Kemeny's framework is applied to review the extent to which public housing has moved away from a 'command' system to a more market sensitive model. The analysis starts with a review of the three critical elements characterising the public housing sector -ownership, rent and allocation policies. We are using the term public housing to define the social rented sector. In both countries social housing at the moment is a subcategory of municipal housing. ${ }^{\mathrm{i}}$

\section{Figure 2 Eastern Europe Social Rental Sector in 2001}

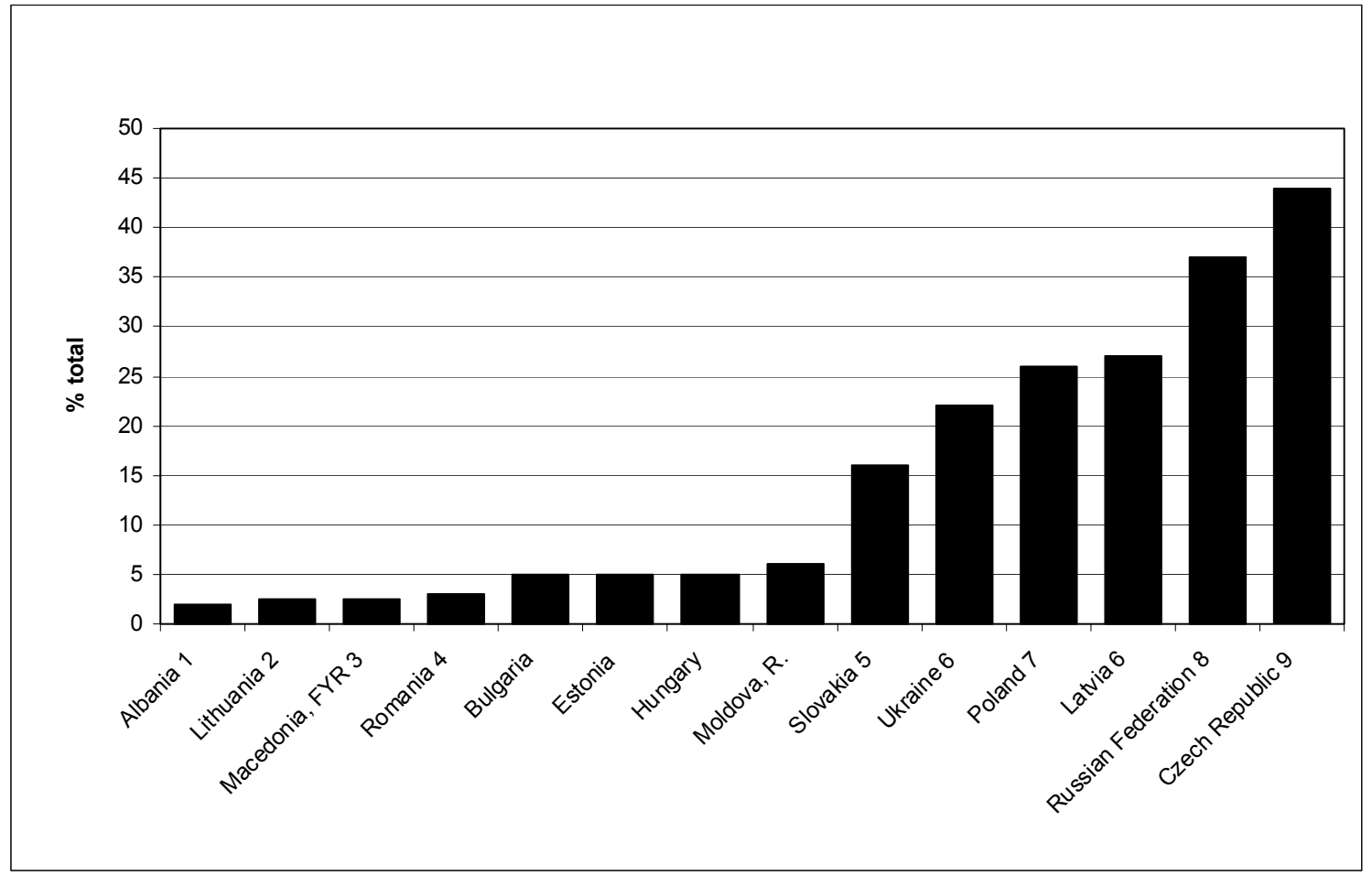

Source: Adapted from http://www.iut.nu/ (International Union of Tenants)

Notes:

*1 Ministry of Territory Planning and Tourism, Tirana

*2 Ministry of the Environment, Vilnius

*3 Habitat National report, Macedonia 2001

*4 Ministry of Public Works, Transport and Housing, Bucharest

*5 Slovak Tenant Association

*6 Authors' estimates.

*7 Polish Ministry of the Environment Office for Housing and Urban Development

*8 Gosstroy of Russia. Moscow

*9 Czech Statistical office, Census 2001 


\section{LATVIA AND UKRAINE: THE HOUSING POLICY CONTEXT}

Latvia is one of the few post-communist countries where the state is almost invisible in housing matters. Direct housing subsidies from the state budget have been eliminated and municipalities have acquired autonomy in the management of public housing as well as in the provision of housing assistance. This devolution in governance, essentially beneficial for locally appropriate responses to housing market conditions, has left a lot of unfunded mandates. Surveys have indicated that most municipalities have difficulties providing demand-based housing assistance and refrain from investment in public housing (Tsenkova 2002).

In Ukraine, despite some attempts to reduce housing subsidies, new programs for construction or purchase of dwellings for specific groups have been introduced. While the results have been limited, the subsidy 'loading' is non-negligible and the targeting tends to be rather low (Turner 2003). The most important part of the Ukrainian housing policy is the allocation system based on waiting lists from the communist past, which has continued to exist despite the small numbers of dwellings to allocate. In addition, Ukraine still keeps a detailed discount system of various benefits, including support for utilities and rent (Tkachenko et al. 2002).

In both countries housing policy challenges need to be understood against the background of housing shortages, particularly in urban areas, overcrowding and relatively low housing standards. The data indicate that both countries have on average 21 sq.m housing per person, access to water and sanitation is available in half of the housing stock in Ukraine and in two-thirds in Latvia, and over 60 per cent of the households live in overcrowded conditions (SSCU 2002b, CLBL 2002a). The legacy of the Soviet system of housing allocation, where the ratio of one person per room was the ideal target for distributional efficiency, has resulted in overcrowding, particularly visible in the situations of one- and two-room dwellings, but also in over consumption (see Table 1).

Table 1: Latvia and Ukraine: Households Size Combined with Dwelling Size in 2002

\begin{tabular}{|c|l|c|c|c|c|}
\hline \multirow{2}{*}{$\begin{array}{c}\text { Household } \\
\text { Size }\end{array}$} & \multirow{2}{*}{ Country } & \multicolumn{4}{|c|}{ Dwellings by Number of Rooms (\%) } \\
\cline { 3 - 6 } & & 1 room & 2 rooms & 3 rooms & $4+$ rooms \\
\hline 1 person & Latvia & 56,9 & 23,3 & 12,5 & 9,7 \\
\hline & Ukraine & 40,5 & 24,2 & 14,6 & 9,5 \\
\hline 2 persons & Latvia & 26,9 & 34,3 & 23,7 & 17,4 \\
\hline & Ukraine & 26,0 & 33,0 & 28,4 & 24,2 \\
\hline 3 persons & Latvia & 10,3 & 23,2 & 25,5 & 19,3 \\
\hline & Ukraine & 21,8 & 22,3 & 23,7 & 21,5 \\
\hline 4+ persons & Latvia & 5,9 & 19,2 & 38,3 & 53,6 \\
\hline & Ukraine & 11,7 & 20,5 & 33,3 & 44,8 \\
\hline \multicolumn{7}{|l|}{ Total } & Latvia & 100,0 & 100,0 & 100,0 & 100,0 \\
\hline & Ukraine & 100,0 & 100,0 & 100,0 & 100,0 \\
\hline $\begin{array}{l}\text { Source: } \\
\text { Rows 1, 3, 5, 7: Authors estimates based on Latvian Central Statistical Bureau, 2002a } \\
\text { Rows 2, 4, 6, 8: Household Survey for Ukraine 2002 (based on Table 3, 18, 24) }\end{array}$ \\
\hline
\end{tabular}


The decline in new housing construction in the last decade, much more significant in Latvia compared to Ukraine, has aggravated these chronic shortages creating a lot of pressure on municipalities to respond to growing housing need.

\section{CHANGING INSTITUTIONAL CONTEXT IN THE PUBLIC RENTED SECTOR}

\section{Ownership}

Historically municipalities and state institutions have provided public housing in both countries with the state playing a much more significant role in Ukraine. At the start of the reform process, private ownership of housing was mostly limited to single-family homes in rural areas and land was nationalised (Jaffe et al. 1995, Tkachenko et al. 2002). During the Soviet regime a small co-operative sector has established itself in Latvia as an alternative to publicly owned housing in large urban areas. Co-operative members in need of housing' were allowed to use a heavily subsidised credit to purchase a share in the housing coop thus acquiring exclusive rights to occupy their dwelling (Tsenkova 2000). Recently, restitution (in Latvia) and privatisation in both countries have reduced the size of the public rented housing leading to some non-traditional ownership arrangements. Privatised units are typically found in publicly owned buildings. The transfer of property rights related to the building envelope and the land in the case of multi-family buildings has not been an explicit emphasis of the privatisation and might take years to complete. Ukraine does not appear to have a consistent policy to facilitate the process, while Latvia has initiated some capacity building programs to assist the formation of homeowners associations. This 'transitional element' in the ownership structure in reality expands significantly the size of the public sector and the mandate of social housing landlords (Tsenkova 2003b). ${ }^{\text {ii }}$

\section{Privatisation}

Despite its 'late start', privatisation of public housing in Latvia has increased private ownership by 38 per cent (Figure 3 ). Interviews with officials suggest that the process has gained momentum in the last three years. In Ukraine agressive privatization policies transfered close to 72 per cent of the public stock, mostly free of charge, to sitting tenants in the early 1990s (SSCU 2002). The remainder of the stock, with the exception of 7 per cent which are not eligible for privatization ${ }^{\text {iii }}$, continues to be privatized. In Latvia, restitution or return of nationalized properties to former owners preceeded mass privatization. The process was significant in Riga, where close to 6 per cent of the stock has been denationalized (Tsenkova 2003b). Tenants in state and municipal housing can use privatisation vouchers to purchase their unit. The value of a voucher officially was estimated at 28 Lats in the early 1990 s, corresponding to 0.5 sq.m. of residential space. ${ }^{\text {iv }}$ The deadline for the voucher privatisation has been extended several times. Both forms of privatization through vouchers or free transfer to tenants are motivated by political considerations and economic efforts to restructure the housing sector on market principles (Jaffe et al 1995; Kursis, 1999). There has been little, if any, systematic evaluation on the 
impact of these policy measures on the housing market. In both countries a moratorium on housing privatisation is considered politically unpopular.

Figure 3 Housing Ownership Transformation in Latvia and Ukraine, 1992-2000

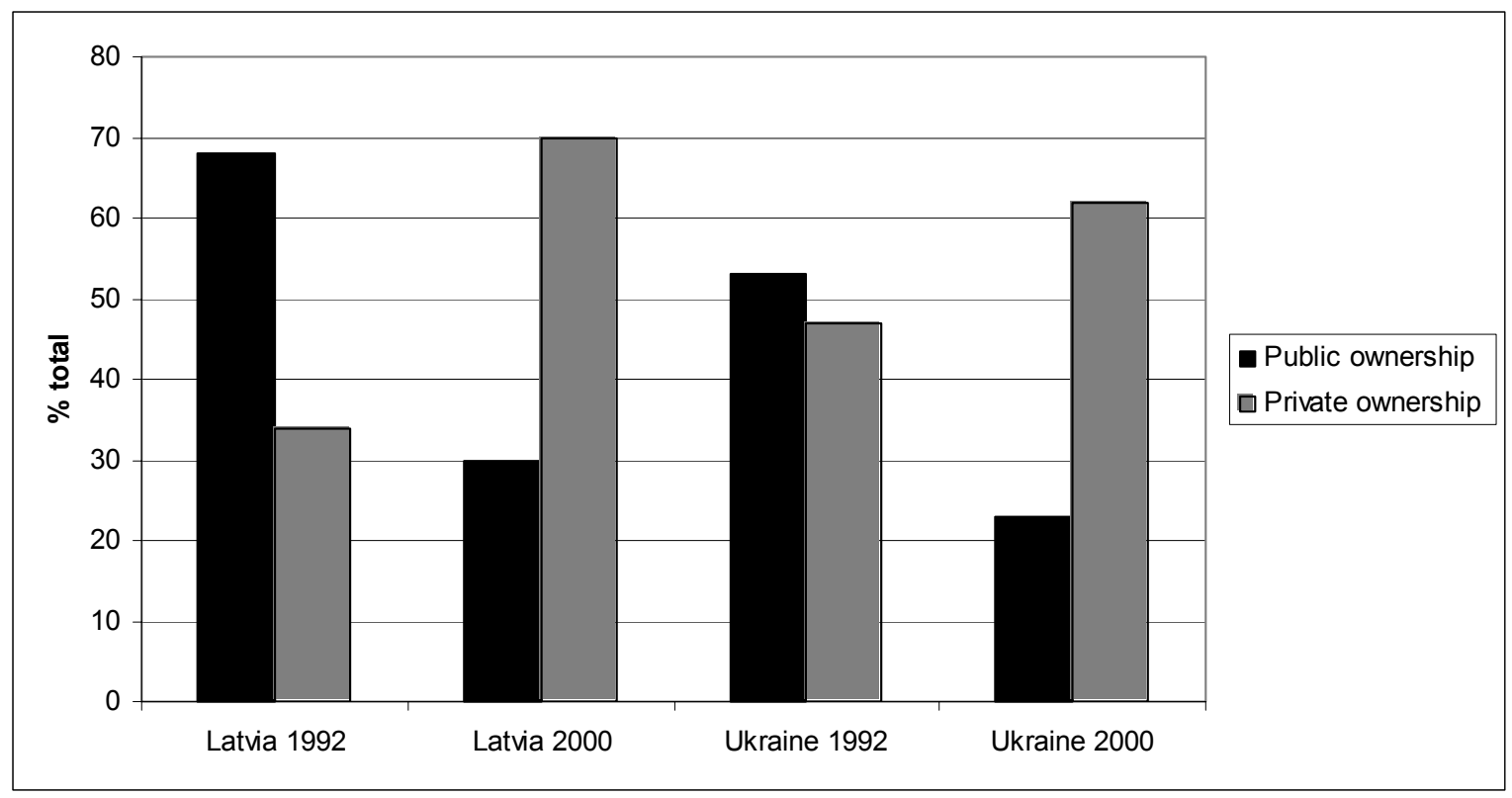

Source: Latvia: Authors' estimates based on data from MoEPRD, 2001 and Central Statistical Bureau, 2002a; Ukraine: Statistical Yearbook of Ukraine 2001

Notes:

Latvia: the category 'public' for 1992 includes housing owned by state institutions, enterprises and municipalities, while private includes coops and owner occupied housing. In 2000 private housing includes private denationalised housing.

Ukraine: the category 'pubic' refers to state, collective and communal housing. Since 2001 communal/municipal housing is considered a separate category of ownership.

\section{Rent Setting}

Previously highly dependent on central government control, municipalities have become the new social landlords. The institutional reforms in the housing system, and the new financial regime for operation, allow more autonomy in decision-making but also imply a growing social responsibility to deal with poverty and social stress. Reforms in the legal framework provide the opportunity to set rents in the municipal boundaries, which is a radical departure from the previous policy of state controlled rent levels. In Latvia, the legislation permits rents to be differentiated according to quality and location of housing. The available data on rents in the seven republican cities indicate significant differentiation with rent levels in Ventspils and Jurmala 50 per cent higher than the average (Central Housing Privatisation Commission Survey 2002). 
Despite differentiation among cities in Latvia, rents are set below market levels, with 'flat' rent structures not reflecting the value or the location of the property, which is characteristic of a 'command' system. In practice, municipalities in Latvia and Ukraine are pooling costs across the stock. Housing managers state that rents barely cover operation costs, but introducing cost recovery for housing services tends to be politically unpopular (COWI 2002, Turner 2003). Correspondingly, municipal maintenance companies carry out marginal upkeep and resort to patchwork maintenance and emergency repairs. Anecdotal evidence suggests that in Riga rents in public housing are close to 20 per cent of private sector rents, while in Kiev the share is lower than 10 per cent.

In addition, tenants and owners pay an equal amount for the maintenance of the building, which is labelled as 'rent'. Rent structures are not sensitive to demand and there is no mechanism for exit from the sector when the household's income increases above a certain threshold. This policy of uniform rents is a form of universal subsidy, which essentially continues to be in force even after the Soviet regime has collapsed. What is more important is that because of its poor targeting, it fails to raise much-needed revenue for the investment in multi-family housing thus accelerating deterioration. ${ }^{\mathrm{v}}$

\section{Allocation}

A low rent and a rationing system through waiting lists continues to be the cornerstone of the Ukrainian housing policy. In 2001, 1.6 million households were in line, a major reduction since 1991 when the number was as high as 2,7 million (SSCU 2002a). Due to declining construction of public housing and low turnover, only 29000 households received a dwelling through the allocation system in 2001. Most of them were selected on a needs basis: handicapped, Chernobyl victims, military personel, and households living in unacceptable housing conditions with less than $7 \mathrm{sq} \mathrm{m} /$ person. Oddly enough, low income is not a criteria for receiving a dwelling through the line. This may be seen as a legacy of the communist past, where access to a 'free' dwelling was seen as a social right. The low level of targeting is further emphasized though a new feature, where preference could be given to households wishing to purchase a (new and subsidized) dwelling allocated through the waiting list (Turner 2003).

In Latvia municipalities are given some freedom in designing and managing their allocation systems within centrally set guidelines that established a new residual role for public housing. A characteristic feature of the public housing system is that administrative processes determine its entry point. Since 1993, priority is given to households with special needs: orphans, the handicapped, chronically ill, the elderly and single parents. Most municipalities have revised their housing waiting lists along these lines. Riga, for example, has a long history of housing shortages and close to one third of the residents used to be on the waiting list. The rules have been revised and fewer qualify, but at least 8,500 households ( 3 per cent of the total population) happen to be in the newly established 'housing queue' (Tsenkova 2003b).

The composition of tenants and new owners in public housing in both countries is largely determined by the Soviet allocation system, which operated on the basis of housing need without income being taken into account. At the moment, residential properties owned by the public sector are the home of a wide spectrum of the population. In most of 
the cases one could find a social mix in all neighbourhoods and buildings. However, the new definition of public housing requires vacant units to be allocated to socially disadvantaged and low-income households. Since tenant protection in public housing is still considered to be strong, there is little turnover and almost non-existent vacancy rate in urban areas. Despite the changes in the previous Soviet legislation, which provided lifelong guarantee of tenant rights and provisions for inheritance of rental housing, tenant eviction for non-payment today is costly for the social landlord, takes at least two years to be enforced, and certainly appears to be politically unpopular.

\section{CHANGES IN FINANCIAL SUPPORT FOR PUBLIC HOUSING}

In Ukraine, social suport for housing is offered through a small production oriented program with very different degrees of targeting and the old Soviet style system of rent control with large, partly hidden, subsidies and a low degree of targeting. A detailed discount system supplements the low rent policy on the demand side. Various groups in the society, as schoolteachers and military personnel benefit from discounts related to utility fees as electricity and heating. It is estimated by the Ukrainian authorities that the benefit system is legally underpinned by 26 different laws, roughly corresponding to the same number of beneficiaries/type of benefit.

By contrast, Latvia has eliminated supply subsidies for social housing and moved towards demand-based assistance. The Law on Social Assistance, adopted in 1995, delegated these responsibilities to municipalities and allowed them to determine locally the income level for housing benefits. The support is available to low income households regardless of their tenure status. Under the present regime of fiscal austerity, the practical implementation of this policy is essentially driven by what municipalities can afford, as opposed to rational responses to housing need. Reportedly demand-based housing assistance accounts for 35 per cent of social spending in large municipalities (Social Development Fund 2001). A survey administered to 15 municipalities in Latvia revealed a general consensus that: i) housing assistance is grossly inadequate compared to need, ii) criteria for low income cut-off are set at a very low level so that only the poorest of the poor can qualify, and iii) the funding, which usually amounts to 2 per cent of the municipal budget is limited and distributed 'on a first-come-first-serve basis', which does not mean that it reaches out to all households in need (Tsenkova, 2002).

Without the extensive state support utility costs, particularly for heating, have become a major problem for owners and renters alike. Housing costs, in real terms, have increased in both countries faster than income and account for 14.5 per cent of the average household income in Latvia and 9.7 per cent in Ukraine (CSBL 2002b, SSCU 2002a). In Latvia, close to 10 per cent of the households have previous debt with respect to rent/maintenance payments and in the rental sector this share is as high as 19.7 per cent. Rent arrears have become a wide spread phenomenon creating a lot of pressure for the administration and management of housing. Reportedly in the large cities in Ukraine -Odessa and Kiev -- between 30 and 35 per cent of the utility bills are not paid. The reason is alleged to be a low payment capacity of the population. 


\section{CONCLUSION: THE FUTURE OF SOCIAL HOUSING IN LATVIA AND UKRAINE}

The analysis highlighted that institutional reforms related to rent, allocation and privatization of public housing in Latvia and Ukraine have proceeded through trial and error and do not imply fundamentally new approaches. In practice, the sector still operates like a 'command' system where ownership and management is vested with the state and municipalities and pricing policies are not sensitive to demand or quality of housing services. Allocation decisions in the shrinking portfolio continue to rely on bureaucratic processes, although preference is given to socially disadvantaged households. Maintenance and management is still a municipal monopoly and public landlords manage most of the privatised housing. Although supply-based subsidies have been eliminated, at least in Latvia, uniform rent structures continue to provide poorly targeted implicit subsidies to tenants and owners alike. Ensuring the sustainability of the sector implies moving away from a 'command' system through differentiation of rents, competition in the maintenance and management of housing, the development of a more efficient and transparent housing subsidy system that targets the needy and abolishes general subsidies.

What this means is that Latvia and Ukraine need to make some policy choices and move 'south-west' or 'north-west' in defining the character of their social rented housing. In summary, it is not possible to have it both ways - keep a large social rental sector and operate it as a 'command system' that fails to integrate market signals. The Western European experience demonstrates that there are two principal options for rent setting within the social housing sector. The choice depends on its size and composition of tenants. If the sector is small, it will be a truly social sector, where households are thoroughly selected (closed entry) and with a mechanism for leaving the sector when the household is no longer eligible. In this case, rents may be set as a share of income. This share may in extreme cases be zero for some tenants. We are then close to the old 'in-kind' type of housing policy, when the sector functions more like a safety net. If the social housing sector, however is larger, rents should be set on a cost-recovery basis with housing allowances available to low income households. Latvia has moved in that direction 'north-west' -- but without the necessary consistency and coherence in its approach. The important issue is that a cost recovery rent level makes it possible to simulate market rents and thus have a higher rent in attractive locations. This is the case of unitary systems, where the public sector is competing on a level playing field with the private rented sector and other tenures. While in Ukraine the transition to a more market-oriented system implies that the position of the social rented sector, and particularly its asset management policies, are changing, the choices appear to be more in line with policies pursued in the 'south west' where the sector is residualised and sheltered from market competition. This choice implies further privatization to reduce the size of the sector as well as changes in allocation policies that favour low income households. 


\section{References}

Buckley, R. and S. Tsenkova. 2001. 'Housing Market Systems in Reforming Socialist Economies: Comparative Indicators of Performance and Policy', European Housing Policy 1(2) pp.257-289.

Clapham, D., J. Hegedüs, K. Kintrea and I. Tosics, with H. Kay (eds). 1996. Housing Privatization in Eastern Europe. Westport CT: Greenwood Press.

Central Housing Privatisation Commission. 2002. Survey of Latvian Municipalities, Riga: CHPC, June.

Central Statistical Bureau of Latvia (CSBL). 2001. Privatisation Process in Latvia in 2000. Riga: CSBL.

. 2002a. Results of the 2000 Population and Housing Census. Riga: CSBL. 2002b. Latvia's Regions 2001. Riga: CSBL.

COWI. 2002. Energy Efficiency and Housing Studies Component, Latvia. Riga: MoF Technical Unit.

Harloe, M. 1995. The People's Home: Social Rented Housing in Europe and America. Oxford: Blackwell.

Hegedüs, J., S. Mayo and I. Tosics. 1996. 'Transition of the Housing Sector in the East Central European Countries'. Review of Urban \& Regional Development Studies. 8, pp.101-136.

Heijden, H. van der. 2002. 'Social Rented Housing in Western Europe: Developments and Expectations'. Urban Studies, vol.39 (2), pp. 327-340.

Jaffe A., B. Turner, A. Victorin. 1995. Property Rights and Privatisation in the Baltic Countries. Copenhagen: Nordic Council of Ministers.

Kemeny, J. 1995. From Public Housing to the Social Market: Rental Policy in Comparative Perspective. London: Routledge.

Kursis, J. 1999. Housing Privatisation in the Baltic States. Lund: Lund University.

Lux, M. (ed). 2003. Housing Policy: An End or a New Beginning. Budapest: Local Government Initiative, Open Society Institute.

Marcuse P. 1996. 'Privatisation and its Discontents: Property Rights in Land and Housing in Eastern Europe', in Andrusz, G.; M. Harloe; I. Szelenyi (eds) Cities After Socialism: Urban and Regional Change and Conflict in Post-Socialist Societies. London: Blackwell, pp. 74-145.

Ministry of Environment Protection and Regional Development (MoEPRD). 2001. National Report on Latvia to the UN Conference Istanbul+5. Riga: MoEPRD.

Oxley, M. and J. Smith. 1996. Housing Policy and Rented Housing in Europe. London: E \& FN Spon.

Pichler-Milanovich, N. 2001 'Urban Housing Markets in Central and Eastern Europe: Convergence, Divergence or Policy Collapse'. European Journal of Housing Policy, Vol. 1, pp. 145-187.

Renaud, B. 1996. Housing Finance in Transition Economies: The Early Years in Eastern Europe and the Former Soviet Union. World Bank Policy Research Working Paper 1565. Washington D.C. January

Social Development Fund (2001) Social Assistance in Latvia: Statistical Analysis (Riga, Ministry of Welfare in Latvia). 
Stephens, M. 2002.'International Models of Housing Finance: Housing Finance in the Western and Transition Economies', in Yasui, T. (ed) Housing Finance in Transition Economies, Paris: OECD, pp. 175-182.

Stephens, M., N. Burns and L. MacKay. 2003. The Limits of Housing Reform: British Social Rented Housing in a European Context, Urban Studies, vol. 40 (4), pp. 767-789

Struyk, R. (ed) 1996. Economic Restructuring of the Former Soviet Bloc. Washington D.C: Urban Institute Press.

Struyk, R. (ed) 2000. Homeownership and Housing Finance Policy in the Former Soviet Bloc: Costly Populism. Washington D.C: Urban Institute Press.

Tkachenko, A., K. Alexander and N. Rogozhina. 2002. The Current Status and Potential for Development of the Long-Term Mortgage Lending System in Ukraine - Analytical Report. Moscow: USAID, November.

Tsenkova, S. 2000. Housing in Transition and the Transition in Housing: The Experience of Central and Eastern Europe. Sofia: Kapital Reklama.

Tsenkova, S. 2002. A Concept for a Housing Monitoring System in Latvia. Riga: CityInvest Inc. \& MoEPRD.

Tsenkova, S. 2003a. 'Housing Policy Matters: The Reform Path in Central and Eastern Europe: Policy Convergence?' in Tsenkova, S. and S. Lowe (eds) Housing Change in Central and Eastern Europe: Integration or Fragmentation. Aldershot: Ashgate Publishing Limited, pp.193205.

Tsenkova, S. 2003b. Housing Policy Reforms in Latvia: Challenges and Opportunities. Report for the World Bank. June.

Turner, B., J. Hegedus, I. Tosics (eds). 1992. The Reform of Housing in Eastern Europe and the Soviet Union. London: Routledge.

Turner, B. 2003. Mortgage Finance and Social Housing in Ukraine. Report for the World Bank. August.

United Nations Economic Commission for Europe (2003) Social Housing, Conference Proceedings, Prague: Ministry of Regional Development and Environment.

State Statistics Committee of Ukraine (SSCU). 2002a. Ukraine Household Survey 2002. Kiev: State Statistics Committee of Ukraine.

Ukraine.

(SSCU). 2002b. Statistical Yearbook of Ukraine. Kiev: State Statistics Committee of

\section{Acknowledgement}

The authors acknowledge the support of Social Sciences and Humanities Research Council of Canada. 


\section{Notes}

1. Social housing in Latvia is a municipal property exempt from privatisation that can be rented to low income households. Latvia has 461 social apartments with 3,026 tenants (MoEPRD 2001).In Ukraine, the concept has been introduced in the new housing code approved in June 2003. The legislation states that a dwelling in the social housing sector cannot be privatized or sublet and has to be allocated on social grounds for minimal payment or free of charge.

2. Public ownership (by state enterprises and municipalities) of multifamily residential buildings in Latvia is as high as 93 per cent. Multifamily housing makes up 68 per cent of Latvia's housing stock (COWI 2002).

3. For example, hostels in state or municipal ownership (not enterprise), near railroads etc infrastructure, historic monuments.

4. Introduced in 1992, the distribution system allocated one voucher per person for each year, plus another 15 vouchers for citizenship. The typical family of three ( 2 adults aged 40 years and a 15 year old child) could acquire 140 vouchers sufficient to buy a 70 sq.m. flat. 